\title{
'N VERGELYKENDE ONDERSOEK NA DIE WERKSMOTIVERING VAN BLANKE EN SWART VAKMANNE IN 'N CHEMIESE NYWERHEID
}

\author{
*A.L. BARNARD \\ Departement Bedryf- en personeelsielkunde \\ P.U. vir C.H.O. POTCHEFSTROOM
}

\section{G.C. VENTER}

Sasol Drie

SECUNDA

\begin{abstract}
The work motivation of black and white artisans in a chemical industry. The objective of this study was to determine the extent to which white and black artisans in a chemical industry consider their working environment satisfactory and thus motivating. The results showed no suggestions of an optimally motivating work environment. Black artisans showed a more balanced preference pertaining to extrinsic/intrinsic motivating factors. In contrast, white artisans placed more emphasis on extrinsic motivating factors. The two groups, however, did not differ substantially in their motivational patterns.
\end{abstract}

\section{OPSOMMING}

Die doel met hierdie ondersoek was om met behulp van Lawler en Porter se verwagtingsmodel, vas te stel in watter mate blanke en swart vakmanne, in ' $n$ chemiese nywerheid, hul werksomgewing as toereikend motiverend van aard beskou. Die resultate dui aan dat daar vir beide groepe nie sprake is van ' $n$ optimaal motiverende werksomgewing nie. Terwyl blanke vakmanne ekstrinsieke faktore meer beklemtoon het, het swart vakmanne beter gebalanseerde voorkeure met betrekking tot ekstrinsieke/intrinsieke faktore getoon. Die motiveringspatrone van die twee groepe het egter nie wesenlik van mekaar verskil nie.

Die verbetering van werksprestasie ontvang deurgaans aandag by feitlik alle ondernemings. 'n Behoefte aan optimisering van die prosedure wat gevolg word vir die keuring en plasing van vakmanne het by die organisasie waarin hierdie studie uitgevoer is, ontstaan (Venter, 1989). Heelwat persone is aangestel wat later nie na wense presteer het nie.

Daar is deur Bestuur geredeneer dat psigometriese toetsing wetenskaplik-korrekte aanstellings sou waarborg en dat die bereiking van die primêre, onderliggende doelwit naamlik: die uiteindelike verhoging en verbetering van werksprestasie van die teikengroep, hierdeur in die hand gewerk sou word.

Na deeglike oorweging deur Bestuur is besluit op die implementering van psigometriese toetsing as keuringsmiddel. Daar is egter ook, ooreenkomstig die gedagtegang van Vroom (1964), Porter en Lawler (1968), Lawler (1973) en Van Wyk (1984), besef dat nie alleen daardie eienskappe wat die gestalte van 'n persoon se menswees bepaal en met behulp van toetsing vasgestel kan word nie, maar ook die mate van toereikendheid (al dan nie) van sy werksomgewing en inhoud soos deur ' $n$ werknemer waargeneem, bepalend is vir die mate van motivering waaroor daardie persoon beskik en uiteindelik effektiewe werkprestasie. Dit volg hieruit dat: werkprestasie = f (Mensfaktore + Taak/Omgewingsfaktore).

Aangesien weinig inligting beskikbaar was ten opsigte van vakmanne se persepsies en moontlike verskille (indien enige) tussen dié van blankes en swartes, is besluit om ondersoek te doen na die behoeftes wat bovermelde groepe ten opsigte van hul werksomgewing en -inhoud ervaar, sowel as 'n meting van hulle persepsies ten opsigte van die mate van voldoening/nie-voldoening aan hierdie behoeftes deur die organisasie.

\footnotetext{
*Versoek vir afdrukke moct aan A.L. Barnard gerig word.
}

Die verwagtingsmodel van Porter en Lawler (1968), wat as die omvattendste diagnostiese hulpmiddel (Gordon, 1987) beskou word om motiveringsdeterminante (Van Wyk, 1984) te verklaar en baie nuttig in organisasies aangewend kan word vir die diagnosering en plasing van gedrags- en motiveringsprobleme (Pate, 1987), is geïdentifiseer as die geskikste model om te gebruik.

Oor die navorsingsondersteuning wat die teorie geniet verklaar (Vecchio 1991: 187): "Research on the principles of expectancy theory has generally been supportive". Dieselfde vlakke van geldigheid is verder in studies wat in Japan en die VSA uitgevoer is, gevind (Edwards \& Augustyn, 1986).

Die verwagtingsteorie van motivering is die mees kontemporêre teorie tot beskikking van organisasiesielkundiges. Dit wend 'n sinvolle poging aan om individuele eienskappe, werkseienskappe en werksomgewingseienskappe binne die konteks van 'n enkele teorie te verklaar (Steers \& porter, 1979; Van Wyk, 1984; Gordon, 1987; Vecchio, 1991). Hierdie teorie gaan dus veel verder as behoefte teorieë wat grootliks konsentreer op individuele eienskappe. In hierdie verband beweer Gordon (1987: 115): "Expectancy theory offers a comprehensive view of motivation and integrates many of the elements of the needs, equity, and reinforcement theories. It considers the interface of the individual with both the situation and environment".

In die Suid-Afrikaanse literatuur word relatief min navorsing oor die verwagtingsteorie aangetref. Edwards en Augustyn (1986) het in hulle ondersoek oor die geldigheid van Lawler se verwagtingsteorie vir landelike swart winkelassistente in die Republiek van Transkei genoeg positiewe bewyse gevind dat met ' $n$ redelike sekerheid aanvaar kan word dat die verwagtingsteorie van toepassing gemaak kan word op lae-vlak landelike swart werkers. Myburgh en Coetzee (1986) het in hulle ondersoek oor die taksonomiese struktuur van vergoeding as werkuitkomste, steun gevind vir die taksonomiese verdeling van intrinsieke en ekstrinsieke belonings as werkuitkomstes. 
Wat die toepassing van die verwagtingsteorie in Suid-Afrika betref het Orpen (1976) in 'n vergelykende ondersoek van swart en blanke klerke gevind dat swart klerke se verwagtings swakker was as dié van hulle blanke eweknieë. Terwyl swart klerke in verhouding meer waarde aan ekstrinsieke faktore geheg het, het blanke klerke op hulle beurt weer intrinsieke faktore as meer belangrik beskou. In 'n ondersoek met swart fabriekswerkers het Orpen (1974) ook gevind dat verwesterde swartes, met blankes as verwysingsoproep, meer onrealistiese verwagtinge gehad het as die meer stamgeoriënteerde swartes.

Biesheuvel (1984) het ook die toepaslikheid van Lawler se model ten opsigte van die valensie aspek van vergoeding bekyk en tot die slotsom gekom dat vergoeding slegs die middelinkomstegroep en uitvoerende amptenare sal motiveer indien goeie prestasie erken en in ooreenstemming met verwagtings vergoed word. Marx (1984) het in sy ondersoek oor die gebruik en sukses van motiveringsteorieë deur 128 ondernemings in Suid-Afrika gevind dat die populêre teorieë van Maslow, Herzberg en McGregor meer gebruik word, dog minder sukses behaal as die minder populêre teoriee," soos byvoorbeeld dié van Lawler.

Die verwagtingsmodel van Porter en Lawler (1968) kan as volg voorgestel word:

Motivering $=(\mathrm{E} \rightarrow \mathrm{P}) \times \Sigma((\mathrm{p} \rightarrow \mathrm{o})(\mathrm{V}))$

Hier verwys $(E \rightarrow P)$ na die subjektiewe verwagting of persepsie van die individu dat 'n persoon se pogings wel 'n suksesvolle prestasie (eerstevlak uitkoms) tot gevolg sal hê. Hierdie subjektiewe verwagting word sterk beïnvloed deur elke situasie sowel as vorige ervarings met soortgelyke situasies (Lawler, 1981). Verder verwys $(p \rightarrow o)$ na die werknemer se persepsie of prestasie sekere uitkomste (belonings) tot gevolg sal hê. Hier word twee tipes van uitkomste onderskei naamlik intrinsieke en ekstrinsieke (Lawler 1970, 1973 \& 1981). Eersgenoemde is uitkomste wat die individu aan homself toeken soos byvoorbeeld gevoelens van bevoegdheid, kreatiwiteit en die gevoel dat iets wat die moeite werd is, tot stand gebring is (betekenisvolheid). Laasgenoemde is uit- komste wat voorsien word deur eksterne faktore wat nie met die werk self in verband staan nie soos byvoorbeeld: die organisasie, toesighouer, die werkgroep en vergoeding. Die (V) valensie is die voorkeur/afkeur wat die individu vir 'n bepaalde tweedevlak uitkoms het - die waarde wat 'n persoon dus plaas op ' $n$ bepaalde uitkoms.

Die doelstelling met hierdie ondersoek was om deur middel van ' $n$ gekontroleerde veldeksperiment, geskoei op die verwagtingsmodel van Porter en Lawler (1968), vas te stel in watter mate blanke en swart vakmanne hulle werksomgewing as toereikend en motiverend beskou.

As nulhipotese (Ho) word gestel dat die organisasie ter sprake, na die oordeel van beide blanke en swart vakmanne, voldoen aan hulle werksbehoeftes en bevind genoemde posbekleërs hulself in 'n optimaal motiverende werksomgewing (selfs al verskil die aard van die twee rassegroepe se behoeftes van mekaar). As alternatiewe hipoteses word gestel:

$\mathrm{H1}$ : Swart vakmanne is beduidend swakker gemotiveerd as hul vergelykbare blanke kollegas.

$\mathrm{H} 2$ : Blanke vakmanne heg beduidend groter waarde as swart vakmanne aan die bevrediging van werkverwante behoeftes van intrinsieke aard.

Die bevinding van Alverson (1975) dat by baie blankes die persepsie bestaan dat swartes nie so goed gemotiveer is om goed in hulle werk te presteer as blankes nie sowel as die bevinding van Orpen (1976) dat blanke klerke groter waarde aan intrinsieke faktore heg as swart klerke, was die rasionaal vir die alternatiewe hipoteses.

\section{METODE}

Uitvoering van die eksperimentele gedeelte van hierdie ondersoek is grootliks geskoei op 'n soortgelyke ondersoek onderneem deur Orpen (1976: 365-368), sowel as op riglyne in hierdie verband deur Lawler (1981: 236-239). Die ondersoek is geheel en al gebaseer op Porter en Lawler (1968) se verwagtingsmodel van motivering en is ooreenkomstig die proses, soos uiteengesit in tabel 1, uitgevoer.

\section{TABEL 1: PROSESVERLOOP VAN ONDERSOEK}

\section{STAP PROSES}

1. Die bepaling van die belangrikste werksbehoeftes van blanke en swart vakmanne.

Die bepaling van die belangrikheid (valensie) van hierdie behoeftes ten opsigte van die groepe hierbo genoem. (V)

3.

Die bepaling van alle betrokkenes se verwagtinge ("expectations") ten opsigte van hierdie behoeftes. (E)

4. Die bepaling van betrokke individue se persepsies rakende die instrumentaliteit (I) van hul eie optrede in hul pogings tot die bereiking van sukses.

WYSE UITGEVOER

INLIGTING VERSAMEL/INSTRUMENT

Twee loodsstudies ter identifisering van relevante items en toets vir gesagsgeldigheid. (kyk p. 5/6).

Respondente is versoek om 'n keuse ten gunste van elk van die twintig faktore (kyk tabel 2) te doen.

Respondente is versoek om ten opsigte van die vermelde twintig faktore (in die vorm van positiewe stellings) in stap 2, die mate aan te dui waarin hul glo dat hul eie optrede tot bevrediging van hul behoeftes deur die organisasie sou lei.

Drie algemene vrae, wat geen verband hou met die twintig faktore vermeld in stappe twee tot drie nie, is volgens die riglyne gestel deur Lawler (1981) ingevoeg ter bepaling van respondente se algemene vlak van verwagtinge (instrumentaliteit " $\mathrm{I}$ ").
Informele gesprekvoering en konsensus; Gedwonge keuse en vierpuntskaal wat items van 28 na 20 verminder het (kyk p. 5-7 en tabel 2).

Vierpuntskaal.

Vierpuntskaal.

Vierpuntskaal.

Formule: $\mathrm{M}=\mathrm{V} \times \mathrm{E} \times \mathrm{I}$.

\section{DIE MEETINSTRUMENT}

Twee loodsstudies is uitgevoer ter identifisering van items wat potensieel in die finale meetinstrument opgeneem sou kon word, asook of hierdie items relevant is al dan nie.
Identifisering van items: 'n Klein maar sterk verteenwoordigende steekproef bestaande uit 20 vakmanne (ongeveer $5 \%$ van die teikenpopulasie) is vir hierdie doel op ewekansige wyse getrek. 
Die navorser het deur middel van informele gesprekvoering eers met blanke en daarna met swartes vasgestel wat die onderskeie groepe as hul belangrikste werksbehoeftes beskou. Slegs daardie werkbehoeftes waaroor daar konsensus by die onderskeie groepe was, is ingesluit. 'n Totaal van agt-entwintig faktore (behoeftes) is op hierdie wyse geïdentifiseer.

Bepaling van relevansie: Bogenoemde faktore is hierna in ' $n$ vraelysformaat gegiet en aan ' $n$ groter $(n=40)$ maar steeds verteenwoordigende ewekansig geselekteerde steekproef voorgehou vir stemming met betrekking tot die relevansie daarvan. Betrokkenes is individueel versoek om die agt-entwintig faktore op gedwonge wyse soos volg te selekteer: eers die sewe mees relevante faktore, daarna die sewe mees nierelevante faktore, ensovoorts. Beoordeling met betrekking tot relevansie is aan die hand van die volgende vierpuntskaal gedoen:

1. Onbelangrik vir my

2. Minder belangrik vir my

3. Belangrik vir my

4. Geweldig belangrik vir my

Hierdie oefening is uitgevoer ten einde optimale geldigheid met betrekking tot die items wat in die finale meetinstrument opgeneem sou moes word, te verseker. Hierdie finale instrument is verder vir gesigsgeldigheid getoets deur dit aan 'n aantal kundiges (aan die PU vir $\mathrm{CHO}$ ) voor te lê.

Slegs daardie faktore wat tydens die vorige oefening (bepaling van relevansie) deur beide groepe $(n=40)$ blanke en swart vakmanne as relevant beskou is, is in die finale meetinstrument opgeneem. Twintig faktore is op hierdie wyse geïdentifiseer (kyk tabel 2).
Die finale instrument is aan die hand van riglyne deur Lawler (1981: 236-239) opgestel. Die faktore soos hierbo bespreek, is eenvoudig en in die vorm van positiewe stellings, soos onder andere "Die hoeveelheid geld wat $\mathrm{u}$ as salaris ontvang", aangebied. In tabel 1 (stappe twee tot vier) word sowel die drie afdelings as die wyses waarop die meting van valensie, verwagting en instrumentaliteit plaasgevind het, uiteengesit.

Geen tydsbeperking is op die voltooiing van die meetinstrument geplaas nie. Daar is ook deurgaans van gestandaardiseerde instruksies aan respondente ten opsigte van die voltooiing van die instrument gebruik gemaak. Die proefpersone is deur een persoon in groepe getoets.

\section{STEEKPROEFSAMESTELLING}

By die organisasie hier ter sprake word, ten spyte van deurlopende natuurlike personeelomset, 'n gemiddelde bemanningsterkte (teikenpopulasie) van 358 blanke en 29 swart vakmanne gehandhaaf - 'n totaal van 387. 'n Relatief groot ewekansige steekproef van 204 blanke vakmanne (57\%) en al 29 swart vakmanne $(100 \%)$ is getrek $(60,2 \%$ van die teikenpopulasie), sodat daar met vertroue ten opsigte van die bevindinge veralgemeen kan word na die teikenpopulasie.

\section{RESULTATE EN BESPREKING}

Blanke Vakmanne

Die stand en aard van motivering ten opsigte van blanke vakmanne word in tabel 2 weergegee.

TABEL 2: DIE STAND EN AARD VAN MOTIVERING VAN BLANKE VAKMANNE

\begin{tabular}{|c|c|c|c|c|c|c|c|c|c|}
\hline $\begin{array}{l}\text { MEETINSTRUMENTITEMS/ } \\
\text { FAKTORE (SLEGS VAN } \\
\text { TOEPASSING OP E EN V } \\
\text { HIERNAAS EN NIE OP I } \\
\text { NIE }\end{array}$ & $\begin{array}{c}\text { AARD VAN } \\
\text { FAKTOR (EK- } \\
\text { STRINSIEK } \\
\text { OF IN- } \\
\text { TRINSIEK) } \\
\end{array}$ & $\begin{array}{l}\bar{X}: \text { E (VER- } \\
\text { WAGTING) }\end{array}$ & RANGORDE & $\begin{array}{l}\bar{X}: \mathrm{V} \text { (VA- } \\
\text { LENSIE) }\end{array}$ & RANGORDE & $\begin{array}{c}\bar{X}: E) \\
x \\
(\bar{X}: V)\end{array}$ & $\bar{X}: I$ & $\begin{array}{c}\mathrm{M}=(\overline{\mathrm{X}}: \mathrm{E}) \\
\mathrm{x}(\overline{\mathrm{X}}: \mathrm{V}) \\
\mathrm{x}(\overline{\mathrm{X}}: \mathrm{I})\end{array}$ & $\begin{array}{l}\text { RANGORDE } \\
\text { TOV } \\
\text { GEMOTI- } \\
\text { VEERDHEID }\end{array}$ \\
\hline $\begin{array}{l}1 \text { Salarisverhoging } \\
2 \text { Bonus (byvoorbeeld } \\
\text { produksiebonus) } \\
3 \text { Lof (vir goeie resultate) } \\
4 \text { Bystand en onder- } \\
\text { steuning } \\
5 \text { Aanvaarding van } \\
\text { idees/voorstelle } \\
6 \text { Gereelde terugvoer } \\
7 \text { Bevordering } \\
8 \text { Opleiding } \\
9 \text { Respek (van } \\
\text { medewerkers) } \\
10 \text { Nuwe uitdagende werk } \\
11 \text { Werksekuriteit } \\
12 \text { Betekenisvolle werk } \\
13 \text { Ingelig oor doel van op- } \\
\text { dragte } \\
14 \text { Verantwoordelikheid } \\
15 \text { Ontvang moeilike op- } \\
\text { dragte } \\
16 \text { Ontvang trofee (beste } \\
\text { werker) } \\
17 \text { Geldelike vergoeding vir } \\
\text { voorstelle } \\
18 \text { Bo-normale meriete } \\
19 \text { Outonomiteit } \\
20 \text { Gelyke geleenthede }\end{array}$ & $\begin{array}{l}\text { I } \\
\text { I } \\
\text { E } \\
\text { I }\end{array}$ & $\begin{array}{l}2,85 \\
2,83 \\
3,36 \\
3,10 \\
\\
3,00 \\
3,18 \\
3,21\end{array}$ & $\begin{array}{l}10 \\
11 \\
1 \\
5 \\
6,5 \\
4 \\
3\end{array}$ & $\begin{array}{l}2,51 \\
2,90 \\
3,25 \\
2,65 \\
\\
2,50 \\
2,54 \\
2,49\end{array}$ & $\begin{array}{c}12 \\
11 \\
4 \\
2 \\
\\
16 \\
7 \\
3 \\
9 \\
17 \\
13,5 \\
18\end{array}$ & $\begin{array}{r}7,56 \\
7,72 \\
6,68 \\
6,02 \\
8,34 \\
\\
7,15 \\
8,21 \\
10,92 \\
8,22 \\
7,50 \\
8,08 \\
7,99\end{array}$ & $\begin{array}{l}3,49 \\
3,49 \\
3,49 \\
3,49\end{array}$ & $\begin{array}{l}26,94 \\
23,31 \\
21,01 \\
29,11 \\
\\
24,95 \\
28,65 \\
38,11 \\
28,69 \\
26,18 \\
28,20 \\
\\
27,89\end{array}$ & $\begin{array}{r}18 \\
8 \\
12 \\
\\
11 \\
15 \\
16 \\
3 \\
\\
14 \\
5 \\
1 \\
4 \\
\\
13 \\
6 \\
\\
7 \\
\\
20 \\
\\
19 \\
10 \\
2 \\
17\end{array}$ \\
\hline TOTALE (GEMIDDELDES) & $9(\mathrm{E}): 11(\mathrm{I})$ & 2,64 & - & 2,74 & - & 7,20 & 3,49 & 25,12 & - \\
\hline
\end{tabular}


Die totale vlak van gemotiveerdheid kan bereken word as:

Werklike M

Totale moontlike M

$=\underline{25,12}$

64

$=0,3925$

Die werklike $\mathrm{M}$ word in tabel 2 verkry. Aangesien die respondente ' $n$ maksimum telling van 4 ten opsigte van elk van " $V$ ", " $\mathrm{E}$ " en " $\mathrm{I}$ " kan behaal, is $64(4 \times 4 \times 4)$ die totale moontlike $\mathrm{M}$ wat behaal kan word.

Uitgedruk as 'n persentasie, blyk dit uit die resultate dat hierdie groep in totaal slegs $39,25 \%$ gemotiveer is. Die resultate behaal deur hierdie groep dui daarop dat heelwat geleenthede bestaan ter vestiging en uitbouing van ' $n$ werksklimaat gunstig vir optimale motivering.

Die drie hoogste en laagste M-tellings (bereik volgens die formule op p. 8 vir elke individuele item) kontrasteer soos volg: Werksekuriteit $(59,55 \%)$, Outonomie $(46,67 \%)$ en Opleiding $(45,48 \%)$ teenoor Bonus $(24,27 \%)$, Geldelike vergoeding vir voorstelle $(19,69 \%)$ en Ontvang trofee $(17,89 \%)$. Hierdie lae vlak van individuele tellings dui daarop dat die grootte van die totale M-telling beslis nie misleidend is nie.

Die totale (gemiddelde) tellings behaal op E (verwagting) en $\mathrm{V}$ (valensie) verskil slegs 0,10 (kyk tabel 2), wat statisties onbeduidend is. ' $n$ Verdere ontleding van die verhouding tussen die faktore $\mathrm{E}$ en $\mathrm{V}$ toon die volgende:
- Feitlik gelyke E en V-tellings: Gereelde terugvoer Nuwe uitdagende werk Werksekuriteit

- Groter E as V-tellings:

Ontvang moeilike opdragte Outonomiteit Verantwoordelikheid

- Groter V as E-tellings:

Salarisverhoging

Bonus

Bevordering

Dit is opmerklik dat V-tellings (kyk tabel 2) ten opsigte van faktore: salarisverhoging, bonus en bevordering (almal ekstrinsieke faktore) die E-tellings in hierdie gevalle met 'n gemiddelde van $87,43 \%$ oorskry, terwyl daar nie so 'n groot afwyking aangeteken word in gevalle waar E-tellings, V-tellings oorskry nie. Hierdie tendens mag dui op swak vertroue in die vermoë van Bestuur om te voldoen aan werknemers se werksverwante behoeftes, met al die nadelige gevolge van lae gemotiveerdheid.

'n Vergelyking van V-tellings behaal op al die intrinsieke $(\hat{x}=2,58)$ en ekstrinsieke $(\hat{x}=2,94)$ faktore (kyk tabel 2$)$ toon dat eersgenoemde laasgenoemde met $13,96 \%$ oorskry. Saam beskou met die bevinding dat die eerste ses belangrikste faktore (kyk rangordes in tabel 2) egter ook van 'n ekstrinsieke aard is, kan die afleiding gemaak word dat die motiveringswaarde van ekstrinsieke faktore vir hierdie groep baie belangrik is.

\section{Swart Vakmanne}

Die stand en aard van motivering ten opsigte van swart vakmanne word in tabel 3 weergegee.

TABEL 3: DIE STAND EN AARD VAN MOTIVERING VAN SWART VAKMANNE

\begin{tabular}{|c|c|c|c|c|c|c|c|c|c|}
\hline $\begin{array}{l}\text { MEETINSTRUMENTITEMS/ } \\
\text { FAKTORE (SLEGS VAN } \\
\text { TOEPASSING OP E EN V } \\
\text { HIERNAAS EN NIE OP I } \\
\text { NIE }\end{array}$ & \begin{tabular}{|l|} 
AARD VAN \\
FAKTOR (EK- \\
STRINSIEK \\
OF IN- \\
TRINSIEK) \\
\end{tabular} & $\begin{array}{l}\bar{X}: \text { E (VER- } \\
\text { WAGTING) }\end{array}$ & RANGORDE & $\begin{array}{l}\bar{X}: \mathrm{V}(\mathrm{VA}- \\
\text { LENSIE) }\end{array}$ & RANGORDE & $\begin{array}{c}\bar{X}: E) \\
\quad \bar{X}: V)\end{array}$ & $\bar{X}: I$ & $\begin{array}{c}\mathrm{M}=(\overline{\mathrm{X}}: \mathrm{E}) \\
\mathrm{x}(\overline{\mathrm{X}}: \mathrm{V}) \\
\mathrm{x}(\overline{\mathrm{X}}: \mathrm{I})\end{array}$ & $\begin{array}{c}\text { RANGORDE } \\
\text { TOV } \\
\text { GEMOTI- } \\
\text { VEERDHEID }\end{array}$ \\
\hline 1 Salarisverhoging & $\mathrm{E}$ & 2,45 & 16 & 3,43 & 2 & 8,40 & 3,41 & 28,64 & 7 \\
\hline $\begin{array}{l}2 \text { Bonus (byvoorbeeld } \\
\text { produksiebonus) }\end{array}$ & $\mathrm{E}$ & 2,06 & 19 & 2,68 & 9,5 & 5,52 & 3,41 & 18,82 & 17 \\
\hline 3 Lof (vir goeie resultate) & I & 2,93 & 12 & 2,52 & 12 & 7,83 & 3,41 & 25,17 & 10 \\
\hline $\begin{array}{l}4 \text { Bystand en onder- } \\
\text { steuning }\end{array}$ & I & 3,42 & 1 & 2,94 & 6 & 10,05 & 3,41 & 34,27 & 3 \\
\hline $\begin{array}{l}5 \text { Aanvaarding van } \\
\text { idees/voorstelle }\end{array}$ & I & 3,23 & 4 & 2,80 & 8 & 9,04 & 3,41 & 30,83 & 6 \\
\hline 6 Gereelde terugvoer & I & 2,94 & 10,5 & 2,43 & 15 & 7,14 & 3,41 & 24,35 & 12 \\
\hline 7 Bevordering & $\mathrm{E}$ & 2,11 & 18 & 2,93 & 7 & 6,18 & 3,41 & 21,07 & 16 \\
\hline 8 Opleiding & E & 3,06 & 7 & 3,74 & 1 & 11,44 & 3,41 & 39,01 & 1 \\
\hline $\begin{array}{l}9 \text { Respek (van mede- } \\
\text { werkers) }\end{array}$ & I & 2,71 & 14 & 2,33 & 16 & 6,31 & 3,41 & 21,52 & 15 \\
\hline 10 Nuwe uitdagende werk & I & 3,00 & 8,5 & 3,06 & 4 & 9,18 & 3,41 & 31,30 & 5 \\
\hline 11 Werksekuriteit & E & 3,39 & 2 & 3,00 & 5 & 10,17 & 3,41 & 34,68 & 2 \\
\hline 12 Betekenisvolle werk & I & 3,35 & 3 & 2,46 & 14 & 8,24 & 3,41 & 28,10 & 8 \\
\hline $\begin{array}{l}13 \text { Ingelig oor doel van op- } \\
\text { dragte }\end{array}$ & $\mathrm{E}$ & 3,19 & 5 & 2,57 & 11 & 8,20 & 3,41 & 27,96 & 9 \\
\hline 14 Verantwoordelikheid & I & 2,94 & 10,5 & 2,50 & 13 & 7,35 & 3,41 & 25,06 & 11 \\
\hline $\begin{array}{l}15 \text { Ontvang moeilike } \\
\text { opdragte }\end{array}$ & I & 3,00 & 8,5 & 2,16 & 17 & 6,48 & 3,41 & 22,10 & 14 \\
\hline $\begin{array}{l}16 \text { Ontvang trofee (beste } \\
\text { werker) }\end{array}$ & $\mathrm{E}$ & 2,32 & 17 & 1,65 & 20 & 3,83 & 3,41 & 13,06 & 19 \\
\hline $\begin{array}{l}17 \text { Geldelike vergoeding vir } \\
\text { voorstelle }\end{array}$ & $\mathrm{E}$ & 1,81 & 20 & 1,93 & 18 & 3,49 & 3,41 & 11,90 & 20 \\
\hline 18 Bo-normale meriete & $\mathrm{E}$ & 2,61 & 15 & 2,68 & 9,5 & 6,99 & 3,41 & 23,84 & 13 \\
\hline 19 Outonomiteit & I & 3,10 & 6 & 1,68 & 19 & 5,21 & 3,41 & 17,77 & 18 \\
\hline 20 Gelyke geleenthede & I & 2,81 & 13 & 3,35 & 3 & 9,41 & 3,41 & 32,09 & 4 \\
\hline TOTALE (GEMIDDELDES) & $9(\mathrm{E}): 11(\mathrm{I})$ & 2,82 & - & 2,64 & - & 7,50 & 3,41 & 25,58 & - \\
\hline
\end{tabular}


Volgens die reeds vermelde formule (kyk p. 8) blyk dit dat hierdie groep in totaal gesproke $39,97 \%$ gemotiveer is. Hierdie persentasie dui ewe-eens nie op 'n optimaal motiverende werksomgewing nie en hoewel dit ietwat beter is as dié van blanke vakmanne, is die verskil tussen die gemiddeldes van hierdie twee groepe statisties onbeduidend.

Bogenoemde telling behoort teen die agtergrond van ' $n$ fyner ontleding van resultate geïnterpreteer te word. Die drie hoogste en drie laagste totale M-tellings (per individuele item) kontrasteer soos volg: Opleiding (60,95\%, Werksekuriteit $(54,19 \%)$ en Bystand en ondersteuning $(53,55 \%)$ teenoor Geldelike vergoeding vir voorstelle (18,59\%), Ontvang trofee $(20,41 \%)$ en Outonomiteit $(27,77 \%)$

Dit is opmerklik dat beide groepe vakmanne relatief hoë Mtellings ten opsigte van "werksekuriteit" en "opleiding" versus relatief lae tellings ten opsigte van "ontvang trofee" en "geldelike vergoeding vir voorstelle", behaal.

Tabel 3 dui aan dat die totale (gemiddelde) E- en V-tellings met slegs 0,18 verskil, wat statisties onbeduidend is. ' $n$ Nadere ontleding van die verhouding tussen die faktore $\mathrm{E}$ en $\mathrm{V}$ toon die volgende:
- Feitlik gelyke E en V tellings: Nuwe uitdagende werk Bo-normale meriete Geldelike vergoeding vir voorstelle

- Groter E as V tellings:

Outonomiteit

Ontvang moeilike opdragte Ontvang trofee

- Groter V as E tellings: $\quad$ Salarisverhoging

Bevordering

Bonus

Alhoewel V-tellings, E-tellings met $36,33 \%$ oorskry, is dit opmerklik minder (vir dieselfde drie faktore) as in die geval van blanke vakmanne waar die oorskryding $87,43 \%$ beloop het (kyk p. 9 en tabelle 2 en 3). 'n Groter balans is hier ter sprake.

'n Vergelyking van V-tellings behaal op al die intrinsieke $(\hat{x}$ $=2,57)$ en ekstrinsieke $(\hat{x}=2,73)$ faktore (kyk tabel 3$)$ toon dat eersgenoemde laasgenoemde met $6,23 \%$ oorskry. Hierdie groep heg ook, nes hul blanke kollegas, groter belangrikheid aan ekstrinsiek-georiënteerde werkbehoeftes. Hier is egter nie na aanleiding van die rangordering van V-tellings gedoen (vergelyk tabel 3), sprake van 'n oorheersing van ekstrinsieke bo intrinsieke faktore nie. Hier is eerder sprake van 'n goed gebalanseerde verspreiding van voorkeure.

TABEL 4: BEDUIDENDHEIDSBEPALING VAN VERSKILLE TUSSEN GEMIDDELDE $\mathrm{M}(\mathrm{M}=\mathrm{V} \times \mathrm{E} \times \mathrm{I})$-TELLINGS (per individuele vraelysitems sowel as ten opsigte van totale): Blanke en Swart Vakmanne.

\begin{tabular}{|c|c|c|c|c|}
\hline FAKTORE & $\begin{array}{c}\bar{X} \text { M-WAARDE: } \\
\text { BLANKES } \\
\mathrm{N}=204\end{array}$ & $\begin{array}{c}\bar{X} \text { M-WAARDE: } \\
\text { SWARTES } \\
\mathrm{N}=29\end{array}$ & P-WAARDES & $\begin{array}{l}\text { BONFERRONI- } \\
\text { AANPASSING }\end{array}$ \\
\hline $\begin{array}{l}\text { 1. Salarisverhoging } \\
\text { 2. Bonus (Byvoorbeeld produk- } \\
\text { siebonus) } \\
\text { 3. Lof (vir goeie resultate) } \\
\text { 4. Bystand en ondersteuning } \\
\text { 5. Aanvaarding van } \\
\text { idees/voorstelle } \\
\text { 6. Gereelde terugvoer } \\
\text { 7. Bevordering } \\
\text { 8. Opleiding } \\
\text { 9. Respek (van medewerkers) } \\
\text { 10. Nuwe uitdagende werk } \\
\text { 11. Werksekuriteit } \\
\text { 12. Betekenisvolle werk } \\
\text { 13. Ingelig oor doel van op- } \\
\text { dragte } \\
\text { 14. Verantwoordelikheid } \\
\text { 15. Ontvang moeilike opdragte } \\
\text { 16. Ontvang trofee (beste } \\
\text { werker) } \\
\text { 17. Geldelike vergoeding vir } \\
\text { voorstelle } \\
\text { 18. Bo-normale meriete } \\
\text { 19. Outonomiteit } \\
\text { 20. Gelyke geleenthede }\end{array}$ & $\begin{array}{l}27,57 \\
15,53 \\
27,81 \\
26,38 \\
\\
26,94 \\
23,31 \\
21,01 \\
29,11 \\
24,95 \\
28,65 \\
38,11 \\
28,69 \\
26,18 \\
28,20 \\
27,89 \\
11,45 \\
12,60 \\
27,12 \\
29,87 \\
20,97\end{array}$ & $\begin{array}{l}28,64 \\
\\
18,82 \\
25,17 \\
34,27 \\
\\
30,83 \\
24,35 \\
21,07 \\
39,01 \\
21,52 \\
31,30 \\
34,68 \\
28,10 \\
\\
27,96 \\
25,06 \\
22,10 \\
\\
13,06 \\
\\
\\
11,90 \\
23,84 \\
17,77 \\
32,09\end{array}$ & $\begin{array}{l}0,7229 \\
0,1053 \\
0,5954 \\
0,0118^{\star} \\
0,1864 \\
0,4079 \\
0,4650 \\
0,0002^{\star \star} \\
0,4059 \\
0,3493 \\
0,2862 \\
0,2069 \\
0,6259 \\
0,4999 \\
0,0393^{\star} \\
0,2011 \\
0,9080 \\
0,2387 \\
0,0001^{\star *} \\
0,0011^{\star *}\end{array}$ & $\begin{array}{l}0,0002^{\star \star} \\
0,0022^{\star \star}\end{array}$ \\
\hline TOTALE (GEMIDDELDES) & 25,12 & 25,58 & - & \\
\hline
\end{tabular}

Beduidendheidspeile: $\star 5 \%$

$$
\text { ** } 1 \%
$$

\section{Vakmanne: Blankes en Swartes}

Tabel 4 dui aan dat daar, na die Bonferroni-aanpassing (Morrison, 1976), slegs ten opsigte van vier van die twintig motiveringsfaktore $(20 \%)$, beduidende verskille tussen blanke en swart vakmanne bestaan naamlik:
- Bystand en ondersteuning: 5\% peil (M-waarde: Swartes > Blankes)

- Opleiding: $1 \%$ peil (M-waarde: Swartes > Blankes)

- Outonomiteit: $1 \%$ peil (M-waarde: Blankes > Swartes)

- Gelyke geleenthede: $1 \%$ peil (M-waarde: Swartes > Blankes) 
Hierdie baie min beduidende verskille wil dus veel eerder op ooreenkomste as verskille tussen die twee groepe dui. Nogtans, vir 'n meer optimaal motiverende werksomgewing, is dit duidelik dat Bestuur veral aandag sal moet gee aan die hoë verwagtings wat swart vakmanne koester ten opsigte van gelyke geleenthede en geleenthede tot verdere opleiding, terwyl blanke vakmanne veral groter outonomiteit verlang.

\section{GEVOLGTREKKINGS}

Die twee groepe stem ooreen in dié opsig dat daar nie ten opsigte van een van hulle sprake is van 'n optimaal motiverende werksomgewing nie. Die nulhipotese, naamlik dat daar by die organisasie ter sprake na die oordeel van blanke en swart vakmanne aan hulle werksverwante behoeftes voldoen word, word dus verwerp.

Wanneer na die resultate van t-toetse uitgevoer ten opsigte van die twee groepe gekyk word, blyk dit dat beduidende verskille slegs ten opsigte van $20 \%$ van die vraelysitems (20) bestaan (kyk tabel 4). Dit blyk dat ten opsigte van hierdie verskille swartes in $55 \%$ van die gevalle groter M-tellings as blankes behaal. Hieruit kan die afleiding, soos vroeër gemaak, bevestig word, naamlik: dat dit in die algemeen blyk dat swartes effens beter gemotiveerd is as blankes. Die eerste alternatiewe hipotese naamlik dat blanke vakmanne beter gemotiveerd is as hul swart kollegas, word gevolglik ook verwerp.

Dit blyk voorts dat alhoewel daar ' $n$ mate van ooreenstemming in die motiveringspatrone van blanke en swart vakmanne voorkom, swartes egter beter gebalanseerde voorkeure met betrekking tot ekstrinsieke/intrinsieke motiveringsfaktore as blankes handhaaf. Blankes plaas egter meer klem op ekstrinsieke faktore. Hiermee word dan die laaste alternatiewe hipotese dat blanke vakmanne groter waarde as swartes aan intrinsieke behoeftes heg, verwerp. Hierdie bevinding verskil dus van 'n soortgelyke ondersoek wat deur Orpen (1976) met blanke en swart klerke in Suid-Afrika onderneem is. Hy het gevind dat swart klerke ekstrinsieke en blanke klerke intrinsieke faktore beklemtoon. Alhoewel die teikengroepe verskil, moet die wegbeweeg van beperkende arbeidswetgewing en diskriminerende praktyke, asook 'n vernouing van die loongaping, sekerlik 'n rol gespeel het in hierdie verskuiwing.

Uit bostaande is dit duidelik dat hierdie twee groepe nie wesenlik van mekaar verskil nie. Beide groepe bevind hulself in werksomstandighede wat nie optimaal motiverend is nie terwyl daar ' $n$ mate van ooreenstemming bestaan in behoefte-voorkeure. Voorts dui die t-toets-resultate ook eerder op ooreenstemming as op verskille tussen groepe.

Uit die resultate van die navorsing blyk dit duidelik dat Bestuur baie sal moet doen om 'n meer optimaal motiverende werksomgewing te skep. Aandag sal veral gegee moet word aan die hoë verwagtings wat swart vakmanne koester ten opsigte van groter bystand en ondersteuning, gelyke geleenthede en geleenthede vir verdere opleiding terwyl blanke vakmanne veral groter outonomiteit verlang. Moontlike verskuiwings ten opsigte van behoefte-voorkeure (vergelyk verskille gevind by die Orpen (1976) ondersoek), sowel as die uitwerking wat ingrypende veranderinge op die ekonomiese, politieke en arbeidsterrein op persepsies en verwagtinge kan hê, behoort gemonitor te word.

Dit is wenslik dat opvolgstudies met ander teikengroepe in hierdie en in ander organisasies gedoen word. Gebreke in hierdie studie soos die feit dat geen interne betroubaarheid deur byvoorbeeld inter-korrelasies vir die twintig motiveringsfaktore bereken is nie, sowel as die gebruikmaking van meer gesofistikeerde ontledingstegnieke, behoort dan veral aandag te ontvang.

\section{VERWYSINGS}

Alverson, H.S. (1975) Africans in South African industry: the human dimension. In S.J. Morse \& C. Orpen (eds.), Contemporary South Africa: A Social Psychological Perspective. Cape Town: Juta.

Biesheuvel, S. (1984) Work motivation and compensation. Volume 1. Johannesburg: McGraw-Hill.

Gordon, J.R. (1987) Organizational Behavior. London: Allyn \& Bacon.

Edwards, N.A. \& Augustyn, J.C.D. (1986) A validation study of Lawler's expectancy model on low-level rural Black workers. Journal of Industrial Psychology, 12(1): 17-21.

Lawler, E.E. Job attitudes and employee motivation: Theory, research and practice. Personnel Psychology, 1970, 23, 223-237.

Lawler, E.E. (1973) Motivation in work Organizations. Belmont, California: Wadsworth.

Lawler, E.E. (1981) Pay and organization development Reading, Mass, Addison-Wesley.

Marx, F.W. (1984) Personeelmotivering en -opleiding in SuidAfrika. Navorsings Bulletin, 14(2): 60-61.

Morrison, E.L. (1976) Multivariate statistics. New York: John Wiley.

Myburgh, W.I. \& Coetzee, L.D. (1986) The taxonomic structures of rewards as work outcomes. Journal of Industrial Psychology, 12(1): 3-8.

Orpen, C. (1974) The job expectations of black factory workers. South African Journal of Science, 70: 150-154.

Orpen, C. (1976) The expectancy beliefs, instrumentality beliefs and job reward valances of black and white workers in South Africa. British Journal of Social and Clinical Psychology, 15: 365-368.

Pate, L.E. (1987) Understanding human behavior. Management Decision, 25(6): 58-64.

Porter, L.W. \& Lawler, E.E. (1968) Managerial attitudes and performance. New York: Dorsey-Irwin.

Steers, R.M. \& Porter, L.W. (1979) Motivation and work behavior. New York: McGraw-Hill.

Van Wyk, A.J. (1984) Enkele perspektiewe op motivering. Perspektiewe in die Bedryfsielkunde, 10(1): 45-62.

Vecchio, R.P. (1991) Organizational behavior. Chicago: Dryden Press.

Venter, G.C. (1989) 'n Vergelykende ondersoek na die werksmotivering van blanke en swart vakmanne en kwekelingvakmanne in 'n chemiese nywerheid. Ongepubliseerde skripsie, PU vir CHO., Potchefstroom.

Vroom, V.H. (1964) Work and Motivation. New York: Wiley. 